\title{
Reverse logistics of pesticide packages in Arapiraca, Alagoas - Brazil
}

\author{
Sócrates Mesquita Bomfim ${ }^{1}$ (D), Marcelo Cavalcante ${ }^{1}$ \\ ${ }^{1}$ Programa de Mestrado Profissional em Tecnologias Ambientais, Instituto Federal de Alagoas/Campus Marechal \\ Deodoro. Rua Lourival Alfredo, 176, 57160000, Marechal Deodoro, AL, Brazil. \\ * Autor para correspondência: marcelo.cavalcante@ifal.edu.br
}

Recebido em 15 de junho de 2020.

Aceito em 01 de dezembro de 2020.

Publicado em 31 de dezembro de 2020.

\begin{abstract}
Arapiraca is the municipality of Alagoas with the largest number of cases of poisoning by pesticides, not only due to direct contact with the product, but due to inappropriate disposal of packaging. This research aimed to diagnose the reverse logistics of pesticide packaging in Arapiraca/ AL at eight pesticide dealers, 31 family farmers, technicians responsible for ADRAAL, ADEAL and State Public Ministry, through interviews, using semi-structured questionnaires. Although the dealers provided information on the management of empty pesticide packages $(87.5 \%), 71.4 \%$ of farmers did not return it, burying or burning it most of the time (59.6\%). When returned, the presence of waste was the main problem cited by dealers. A total of 2,341 units and 1,482 $\mathrm{kg}$ of packages were picked by the itinerant service performed by ADRAAL in 2018. ADEAL has a staff limited to 10 workers and lacks a computerized system to control and monitor the use of pesticides. In the 15 inspections in 2017, irregularities were observed in $91.7 \%$ of dealers, with the absence of environmental licensing being the most frequently observed infraction. The results show deficiencies regarding the fulfillment of responsibilities by the actors involved in the reverse logistics process: the dealers, the farmers and the government.
\end{abstract}

Keywords: Public health; Family farm; Legislation; Environment.

\section{Logística reversa de embalagens de agrotóxicos em Arapiraca, Alagoas - Brasil}

Resumo - Arapiraca é o município alagoano com os maiores casos de intoxicação por agrotóxicos do Estado, não somente pelo contato direto com o produto, mas pelo descarte inadequado das embalagens. Esta pesquisa objetivou realizar o diagnóstico da logística reversa de embalagens de agrotóxicos em Arapiraca/AL em nível de oito revendedoras de agrotóxicos, 31 agricultores familiares, responsáveis técnicos pela ADRAAL, ADEAL e Ministério Público Municipal, através de entrevistas, usando questionário semiestruturado. Apesar de as revendedoras fornecerem informações sobre o manejo de embalagens vazias de agrotóxicos (87,5\%), 71,4\% dos agricultores não realizam a devolução, sendo enterradas ou queimadas na maioria das vezes $(59,6 \%)$. Quando devolvidas, a presença de resíduos foi o principal problema citado pelas revendedoras. Um total de 2.341 unidades e $1.482 \mathrm{~kg}$ de embalagens foram captadas pelo serviço itinerante executado pela Adraal em 2018. A ADEAL apresenta quadro limitado a 10 servidores e ausência de sistema informatizado para controle e monitoramento do uso de agrotóxicos. Nas 15 fiscalizações em 2017, foram observadas irregularidades em $91,7 \%$ das revendedoras, sendo a ausência de licença ambiental aquela mais frequentemente observada. Os resultados apresentados demonstram fragilidades quanto 
ao cumprimento das responsabilidades pelos atores envolvidos no processo da logística reversa: revendedores, agricultores e o poder público.

Palavras-chave: Saúde pública; Agricultor familiar; Legislação; Meio ambiente.

\section{Logística inversa del envases de plaguicidas en Arapiraca, Alagoas - Brasil}

Resumen - Arapiraca es el municipio de Alagoas con los más casos de intoxicación por plaguicidas en el Estado, no sólo por el contacto directo con el producto, sino también por la eliminación inadecuada de los envases. Esta investigación tuvo como objetivo diagnosticar la logística inversa de los envases de plaguicidas en Arapiraca/AL a nivel de ocho minoristas de plaguicidas, 31 agricultores familiares, técnicos responsables de ADRAAL, ADEAL y el Ministerio Público Municipal, a través de entrevistas, mediante cuestionario semiestructurado. Aunque los minoristas proporcionan información sobre el manejo de envases vacíos de plaguicidas (87,5\%), el 71,4\% de los agricultores no vueltan los envases que a menudo los enterra o los quema $(59,6 \%)$. Cuando vueltan, la presencia de residuos fue el principal problema mencionado por los minoristas. El servicio itinerante realizado por Adraal en 2018 recogió un total de 2.341 unidades y $1.482 \mathrm{~kg}$ de evases. ADEAL tiene un personal limitado a 10 empleados y la ausencia de un sistema computarizado para controlar y monitorear el uso de plaguicidas. En las 15 inspecciones en 2017, se observaron irregularidades en el 91,7\% de los minoristas, siendo la ausencia de una licencia ambiental la más frecuente. Los resultados presentados demuestran debilidades con respecto al cumplimiento de las responsabilidades por parte de los actores involucrados en el proceso de logística inversa: minoristas, agricultores y el gobierno.

Palabras clave: Salud pública; Agricultor familiar; Legislación; Medio Ambiente.

\section{Introduction}

The expressive use of pesticides in Brazil started approximately 50 years ago, with the advance of the so-called Green Revolution, in which the Brazilian government encourages farmers to adhere to technological applications, which involve the use of improved seeds, agricultural implements, industrialized fertilizers and pesticides in order to increase agricultural research (Serra et al. 2016).

Expressive gains for the economy were achieved with increased productivity and job creation, but, likewise, great environmental impacts are still observed, in the soil (erosion, salinization and desertification), in the water (silting of rivers, eutrophication, leaching pesticides), the atmosphere (increase in greenhouse gases and other pollutants), human health (intoxications, diseases and death) and biodiversity (reduction of native species, natural enemies and increased resistance of pest insects, diseases and weeds).

Pesticides, among the technologies used, are directly related to the unintended effects on living organisms, communities, ecosystems and contamination of water, soil and air. Even with the risks, Brazil leads the world ranking in its use, with herbicides (61.7\%), fungicides (13.4\%) and insecticides (10.4\%), respectively (IBAMA 2019). The soybean, corn and sugarcane crops, together, are responsible for $81.8 \%$ of sales in Brazil (Pignati et al. 2017). In the Northeast region, Alagoas is the 5 th greatest pesticide-buying state $(1,717.88 \mathrm{t})$, with predominance of those with toxicological classes III (920.92 t; 53.6\%) and II (785.13 t; 45.7\%), according to IBAMA (2019), corresponding, respectively, to the medium and highly toxic classes. 
In Arapiraca/AL, located in the Agreste Mesoregion, historically known in Brazil as the land of tobacco, with 246 records, has the highest number of cases of intoxication by pesticides in the State (Bomfim et al. 2019). In this municipality are observed 2,925 agricultural establishments, of which $76.5 \%$ are family-based (Law No. 11,326/2006), where $78.1 \%$ have an area of up to 10 ha, cultivated with diversified vegetable crops (coriander, lettuce, cabbage, pepper and chives), pineapple, cassava, tobacco, beans, corn and pasture (IBGE 2019a). In 2018 the pesticides most sold in Arapiraca were the herbicides 2,4-D (214,000 L), Glyphosate (76,004 L) and Paraquat (34,035 L), in addition to the insecticides Cipermethrin (2,120 L) and Lambda-Cyhalothrin (1,832 L), according to Cavalcante et al. (2020). Considering that $60.8 \%$ of Arapiraca's agricultural establishments use pesticides, the lack of technical assistance identified in $93.9 \%$ of the establishments, associated with the $45.6 \%$ of producers who cannot read and write (IBGE 2019b), may have reflected in the purchase and inadequate handling of pesticides and their packaging, reflecting on intoxications (Silva et al. 2013).

The use of pesticides generates waste, especially packaging, which are potential sources of contamination and environmental pollution. The set of actions, procedures and means designed to enable the collection and return of solid waste to the business sector, for reuse, in its cycle or in other productive cycles, or another environmentally appropriate final destination, is called reverse logistics.

Although Brazil is a successful reference in the reverse logistics of pesticide packaging, family farmers are the problematic group of the process, one which does not return the packaging, an infraction subject to a penalty of two to four years in prision, in addition to a fine (Law No. 9,974, Art. 15). According to Veiga (2008), the reverse logistics process managed by inPEV was initially created to serve large rural areas, with economies of scale that make the process possible and, therefore, may not be adapted to the reality of small rural communities, usually with precarious and more isolated infrastructure.

In human health, the pesticides can cause psychiatric disorders, loss of sensorineural hearing, delayed polyneuropathy (Murakami et al. 2017), with irreversible damage such as cancer, fetal malformation and death (Pignati et al. 2017). In the environment, Leiva et al. (2015) observed that the highly toxic Imidacloprid active ingredient, present in various insecticides, can remain active for 2.6 years, with the potential for leaching and contamination of deep layers and groundwater, in addition to causing bee mortality (Raymann et al. 2018). Song et al. (2015) observed that the by-products generated from the degradation of the insecticide Deltamethrin, extremely toxic, have toxic effects on earthworms, mainly in relation to reproduction. This information reinforces the problems that the accumulation of pesticides can cause in the environment, from the inappropriate disposal of packaging and dosage over the manufacturer recommendations, in cases where the producer increases, on his own, the frequency of application.

This research aimes to diagnose the reverse logistics of empty pesticide packaging in Arapiraca/ AL, Brazil.

\section{Material and methods}

The research was carried out in Arapiraca city (9 45'6" S and 36 39'37' W), between 2018 and 2019. The sample definition followed the recommendations of Miot (2011), for qualitative variables. There are 12 pesticide dealers in Arapiraca, of which eight were interviewed. Considering that in 
Arapiraca there are 200 family farmers registered in the 'CadÚnico' program of the Ministry of Citizenship, it was determined that the sample consisted of 31 family farmers (90\% reliability and $13.7 \%$ margin of error). There are 12 pesticide dealers in Arapiraca, of which eight were interviewed (90\% reliability and 15\% error margin). In all interviews, a qualitative semi-structured questionnaire was considered.

Interviews with resellers adopted the following questions: 1) When selling pesticides, the company informs farmers about washing, packaging, storage, transport and return of empty packages (Law No. 7,802/1989, Art. 7, item II, "d")? 2) The company issues proof of delivery of packages to rural producers and checks the returns against the purchase invoice (Decree 4,074/2002, Art. 55); 3) Do you participate with the public authorities in educational programs and mechanisms to control and encourage the triple washing and return of empty packaging (Law No. 7,802/1989, Art. 19, sole paragraph)? 4) Do you receive supervision on the storage and destination of empty packaging (Decree No. 4,074/2002, Art. 70 to 76)? 5) Is the company informed of the penalties applied for the inappropriate disposal of empty packaging (Law No. 7,802/1989, Art. 14, "e", and Art. 15; Decree No. 4,074/2002, Art. 84)? Information was also requested on the main problems related to the reception of pesticide packaging by resellers. All responses resulted in the terms: never $(\mathrm{N})$, rarely (R), frequently (F) and very often (VO). It was also asked what are the difficulties encountered by the company for the temporary receipt of empty pesticide packaging.

The 31 family farmers were asked about:

a) Return of packaging: 1) Are you informed about the obligation to return empty pesticide packaging (Law No. 7,802/1989, Art. 7, item II, "d”; Decree No. 4,074/2002, Art. 53)? 2) Do you read the instructions on the package inserts and labels of pesticides on the return of packaging (Law No. 7,802/1989, Art. 6, \$2; and Decree No. 4,074/2002, Art. 52)? 3) Do you return the packages to the address indicated in the purchase invoice (Decree No. 4,074/2002, Art. 53, \$2)? 4) When it has expired pesticides, I usually return it (Decree No. 4,074/2002, Art. 53, \$4); 5) Do you bear the costs of transporting the packages to the collection point (Decree No. 4.074/2002, Art. 53, §6)?

b) Triple washing: 1) Are you informed of the need to prepare the packaging for correct disposal (Law 7,802/1989, Art. $6^{\circ}, \S 4^{\circ}$, and Decree $n^{\circ} 4,074 / 2002$, Art. 53, $\$ 5^{\circ}$ )? 2) Are you informed that you need to keep them temporarily stored in an appropriate place on your property (Law No. 7,802/1989, Art. 6, \$2; Decree No. 4,074/2002, Art. 53, \$1)? 3) Do you do the triple washing when foreseen in the instructions for the inserts (Law No. 7,802/1989, Art. 6, $\$ 4$; Decree No. $4,074 / 2002$, Art. 53, \$5)? 4) Do you disable the packaging right after doing the triple wash? (Decree No. 4,074/2002, Art. 53, \$6).

c) Return receipt of packaging: 1) Does the collection station always deliver proof of receipt of packaging (Decree No. 4,074/2002, Art. 53, §3)? 2) Do you keep the purchase invoices and return receipts for empty packaging on file for inspection purposes (Decree No. 4,074/2002, Art. 53, $₫ 3$ )? 3) When you make a new purchase of crop protection products, are you charged by the reseller on the empty packaging of the last purchase (Law No. 7,802/1989, Art. 19, sole paragraph)? 4) Does it regularly receive supervision over the storage, transportation and return of empty pesticide packaging (Law No. 7,802/1989, Art. 12A)? 5) Are you informed of the penalties applied for the inappropriate disposal of empty packaging (Law No. 7,802/1989, Art. 14 and 15)?

All responses presented the following terms as results: never $(\mathrm{N})$, rarely $(\mathrm{R})$, frequently $(\mathrm{F})$ and very often (VO). 
The Administrative Manager of the Association of Distributors and Resellers of Agrochemicals of Alagoas (ADRAAL) was interviewed, addressing the following issues: 1) When he receives the empty packages of pesticides from rural producers, demands purchase invoice, to compare the quantity of packages returned and issue proof of receipt of the packages (Decree No. 4,074/2002, Art. 55)? 2) Do they inspect and classify empty packages between washed and unwashed ones, separating them by type and material (CONAMA Resolution No. 465/2014, Annex I)? 3) Do you participate, together with the public authorities, in educational programs and mechanisms to control and encourage the triple washing of empty packages and their return (Law No. 7,802/1989, Art. 19, sole paragraph)? 4) Do you regularly receive inspection on the storage and destination of empty packaging (Decree $n^{\circ} 4074 / 2002$, Art. 70 to 78)? 5) What are the difficulties encountered by ADRAAL in receiving and disposing of empty pesticide packaging? All packaging of pesticides collected by ADRAAL, by the collection unit in Marechal Deodoro/AL, as well as by the itinerant receipt, held in Arapiraca/AL, for the year 2018 were considered.

An interview was conducted with the head of the Pesticide Nucleus of the Agricultural Defense and Inspection Agency of Alagoas (ADEAL), in which the questionnaire presented the following questions: 1) Does pesticide producing and marketing companies implement, in collaboration with ADEAL, educational programs and mechanisms to control and encourage the return of empty packaging by users (Law No. 7,802/1989, Art. 19)? 2) Does ADEAL receive support from the Federal Government necessary for the control and inspection of the return and proper disposal of empty pesticide packaging (Law No. 7,802/1989, Art. 12)? 3) Does ADEAL have any computerized system that allows the control/monitoring of the return and proper destination of empty pesticide packaging?

The number of inspections carried out to inspect pesticide resellers in Arapiraca was quantified, as well as the main irregularities, according to data from the State Public Ministry, report available for the year 2017.

This research had its project submitted for analysis by the Research Ethics Committee through Platform Brazil, having a consubstantiated opinion approved "without ethical obstacles" under number 3,448,573, according to CNS resolution No. 510/2016.

\section{Results and discussion}

In general, it can be inferred from the resellers' responses regarding procedures, participation and performance in the reverse logistics process, that they sought to comply with their obligations under the shared responsibility system established by the legal process. The average of the very frequent (VO) and frequent (F) results in questions 1 to 3 (Figure 1) showed a percentage of $70.6 \%$, an indicator considered satisfactory for the requirements that the legislation establishes. 
Figure 1. Perception of pesticide resellers in Arapiraca/AL about reverse logistics: Question 1: When selling pesticides, does the company inform farmers about the washing, conditioning, storage, transport and return of empty packaging procedures? Question 2: Does the company issue proof of packaging

delivery to rural producers and compare returns with the purchase invoice? Question 3: Do you participate, together with the government, in educational programs and mechanisms to control and encourage the triple washing and return of empty packaging? Question 4: Do you receive inspection on the storage and destination of empty packaging? Question 5: Is the company informed of the penalties applied for the inappropriate disposal of empty packaging? N: never; R: rarely; F: frequently; VO: very often. ( $\mathrm{n}=$ 08 resellers).

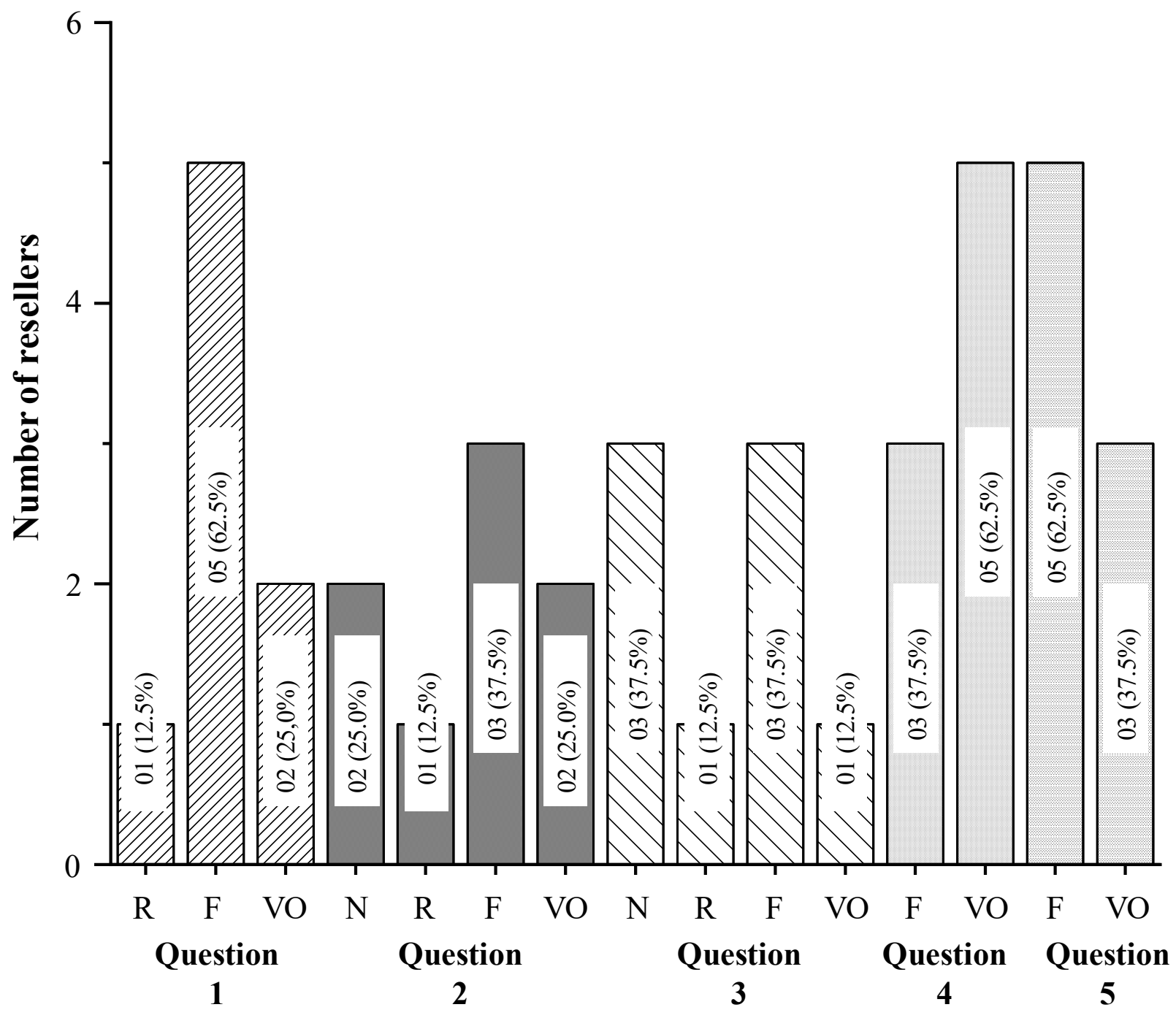

Despite the results, it is worth noting, specifically in Question 3 (Figure 1), that the resellers stated that they never (37.5\%) participated, together with the government, in educational programs and control mechanisms and encouraging the triple washing and return of packaging. The absence of campaigns, when associated with a low level of education (IBGE 2019b), may reflect the significant cases of pesticide poisoning (Bomfim et al. 2019). The research developed by Nogueira et al. (2013) also presented an unsatisfactory result, when $91.7 \%$ of the interviewed farmers stated that they had not received any kind of stimulus regarding the return of pesticide packaging.

In Arapiraca there is no collection point or packaging receiving unit, where returns, when made, are mediated by resellers, who must have adequate facilities for receiving and storing returned 
packaging (Law No. 4,074/2002, Art. 54), as this is a minimum requirement for obtaining the company's environmental license (CONAMA Resolution No. 465/2014). The absence is considered an environmental crime (Law No. 9,605/1998, Art. 60; State Law No. 6,787/2006, Art. 35) passive imprisonment, from one to four years, and a fine (Law 12,305/2010, Art. 53).

Even receiving inspection (62.5\%, Figure 1, Question 4), it was found that $37.5 \%$ of the resellers do not have space to temporarily accommodate the packaging of pesticides (Figure 2), making receipt impossible.

Figure 2. Problems observed by resellers in reverse logistics. ( $\mathrm{n}=8$ resellers).

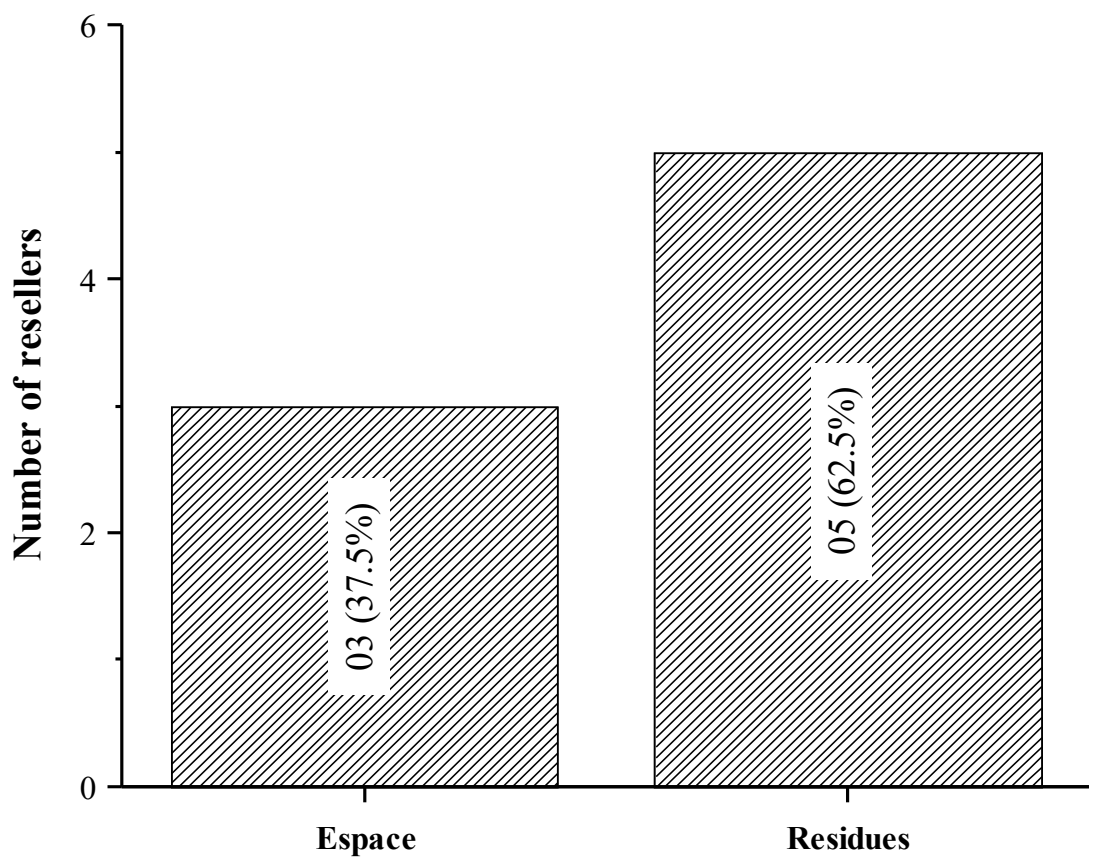

Another recurring problem, mentioned by the resellers, was the presence of product residues in the packaging, a potential source of contamination, which may make receipt impossible, demonstrating the farmers' lack of knowledge about the handling of pesticides and their packaging. In this respect, factors such as the lack of technical assistance observed in $93.9 \%$ of agricultural establishments in Arapiraca (IBGE 2019b), the lack of guidance by resellers at the time of purchase (Figure 1) may have influenced the inadequate return of packaging, which do not go through the recycling process in the processing centers and are incinerated. For Bernardo et al. (2015), the communication between the parties and the disclosure of the necessary information integrates the entire process of returning empty pesticide packaging, so that the reverse logistics can work properly and so that the National Solid Waste Plan has the desired application.

Although $87.5 \%$ of the resellers affirm that they frequently guide the producers on the washing, conditioning, storage, transport and return procedures of empty pesticide packaging (Figure 1), $51.5 \%$ of the farmers stated that they had never received guidance and that resellers were only interested in selling the products (Figure 3 ). These results corroborate those obtained by Bernardo et al. (2015), in $60 \%$ of cases $(n=20)$. 
Figure 3. Family farmers' perception of reverse logistics regarding the return of packaging: Question 1: whether you are informed of the obligation to return empty pesticide packaging? Question 2: If you read the instructions on the package inserts and labels on pesticides on the return of packaging? Question 3: Do you return the packages to the address indicated on the purchase invoice? Question 4: Do you usually return expired pesticides? Question 5: Do you bear the costs of transporting the packages to the collection point? N: never; A: rarely; F: frequently; VO: very often. ( $\mathrm{n}=31$ farmers).

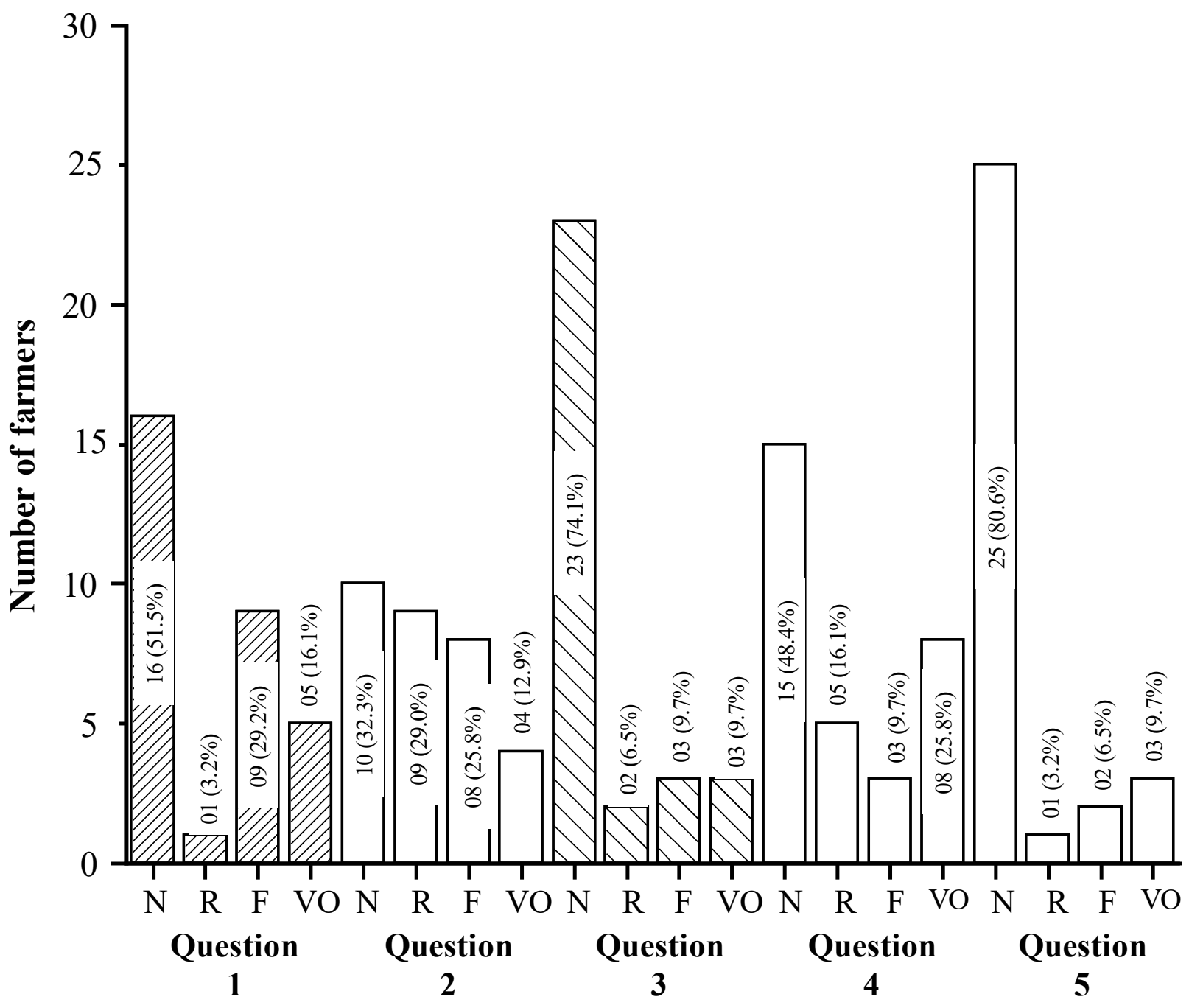

The level of education of the producers (IBGE 2019b) may have influenced the $61.3 \%$ of the interviewees who never or rarely read the pesticide leaflet or label (Figure 3, Question 2), a fact also observed by Sousa et al. (2016), in $60 \%$ of respondents $(n=20)$, this being one of the most relevant factors in exogenous poisoning by pesticides (Leite et al. 2016).

The absence of technical information (educational campaigns, technical assistance or resellers) meant that $71.4 \%$ of the producers did not return the packaging (Figure 4 ), not complying with the current legislation (Law No. 9,974/2000; Decree No. 4,074/2002). Similar results were observed by Gomes et al. (2018), in which $74 \%$ of farmers $(n=254)$ did not return the packaging. However, more expressive results were found by Santana et al. (2016), in 98.2\% of cases $(n=156)$. This information showed that the producer, due to the primary nature of the reverse logistics process, is not fulfilling his duties, compromising the cycle of reuse or the environmentally appropriate final destination of the packaging. 
In cases of expired pesticides (Figure 3, Question 4), 48.4\% did not return and reuse them in their plantations, mixed with valid products. Those who returned $(35.5 \%)$ sent the packages to the collection center with waste (Figure 2), making it impossible for them to be received by some resellers. These packages are considered unsuitable for recycling and are therefore incinerated.

Any form of disposal of pesticide packaging other than its return at the resale or collection center, in an appropriate manner, may reflect on environmental contamination, of people or animals. When buried (29.6\%), burned (29.6\%) or thrown in the field (20.6\%), depending on the soil moisture level (Figure 4), there may be release of the active principle and leaching, reaching the water table and compromising the health of people and animals (Munõz-Leoz et al. 2011; Leiva et al. 2015; Song et al. 2015; Raymann et al. 2018). Burning may also release toxic gases into the atmosphere, putting farmers at risk from inhaling the smoke. Despite understanding the health risks, it was observed that $9.3 \%$ of producers reuse packaging, mainly when transporting water to the countryside. One producer sells empty packages at the open market, showing a complete lack of information.

Figure 4. Destination of pesticide packaging most frequently reported by family farmers in Arapiraca/AL. $(\mathrm{n}=31$ farmers $)$.

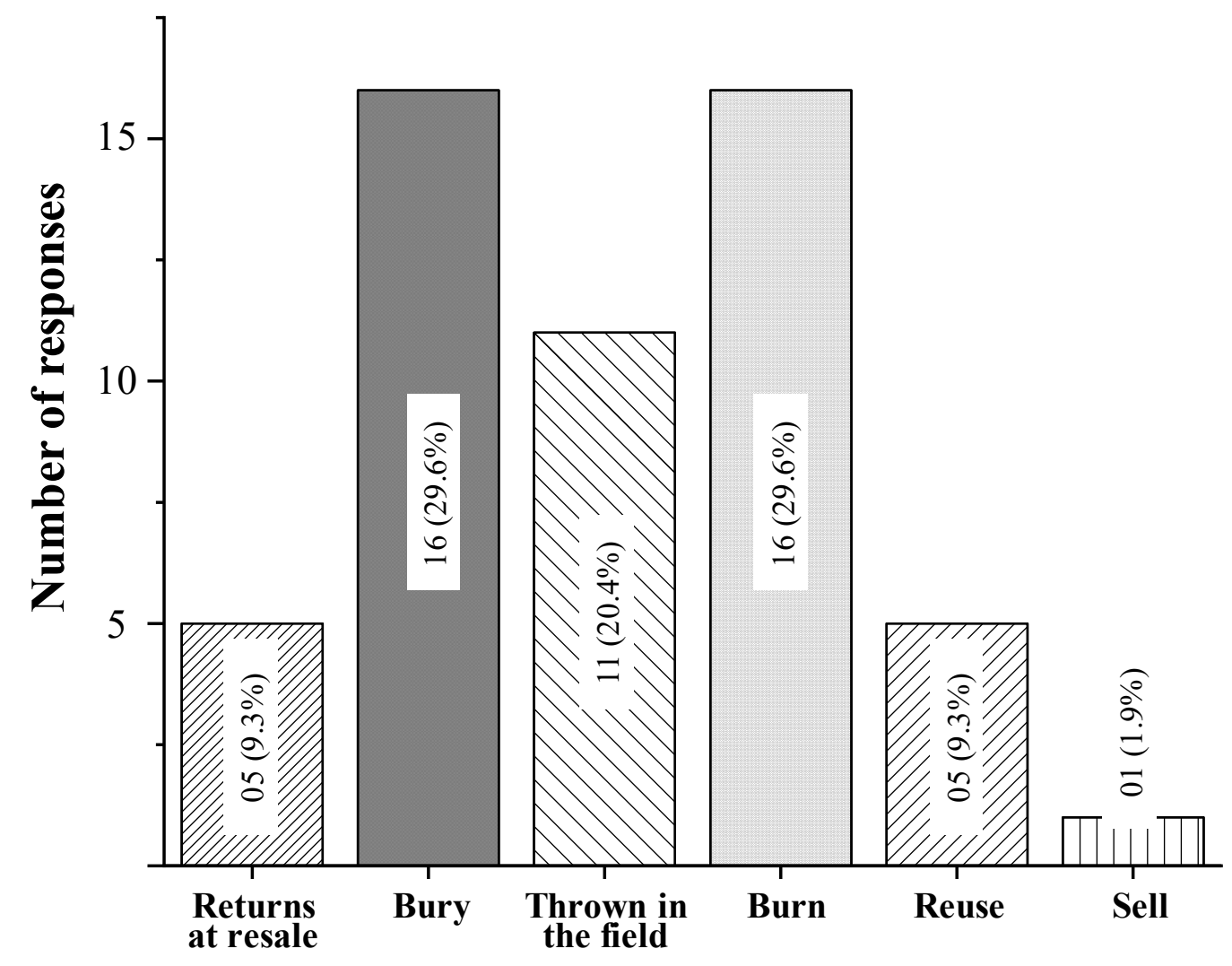

It was observed that more than $50 \%$ of the interviewees were not informed of the need for adequate preparation of empty packaging for correct disposal and temporary storage of packaging (Figure 5), in an appropriate place (ABNT NBR No. 9,843-3/2013), corroborating with the data presented in Figure 1. The absence of technical guidance may have influenced $67.7 \%$ of producers not to carry out the triple washing operation of packaging with miscible or water-dispersible formulations (Law No. 9,974/2000), as well as disabling rigid packaging, practices that hinder reuse, 
as well as failing to guarantee the successful completion of reverse logistics based on packaging recycling.

Figure 5. Family farmers' perception of reverse logistics regarding triple washing: Question 1: Are you informed of the need to prepare packaging for correct disposal? Question 2: Are you informed that you need to keep them temporarily stored in a suitable place on your property? Question 3: Do you do the triple wash when provided in the instructions for use? Question 4: Do you disable the packaging immediately after doing the triple wash? N: never; A: rarely; F: frequently; VO: very often. ( $\mathrm{n}=31$ farmers).

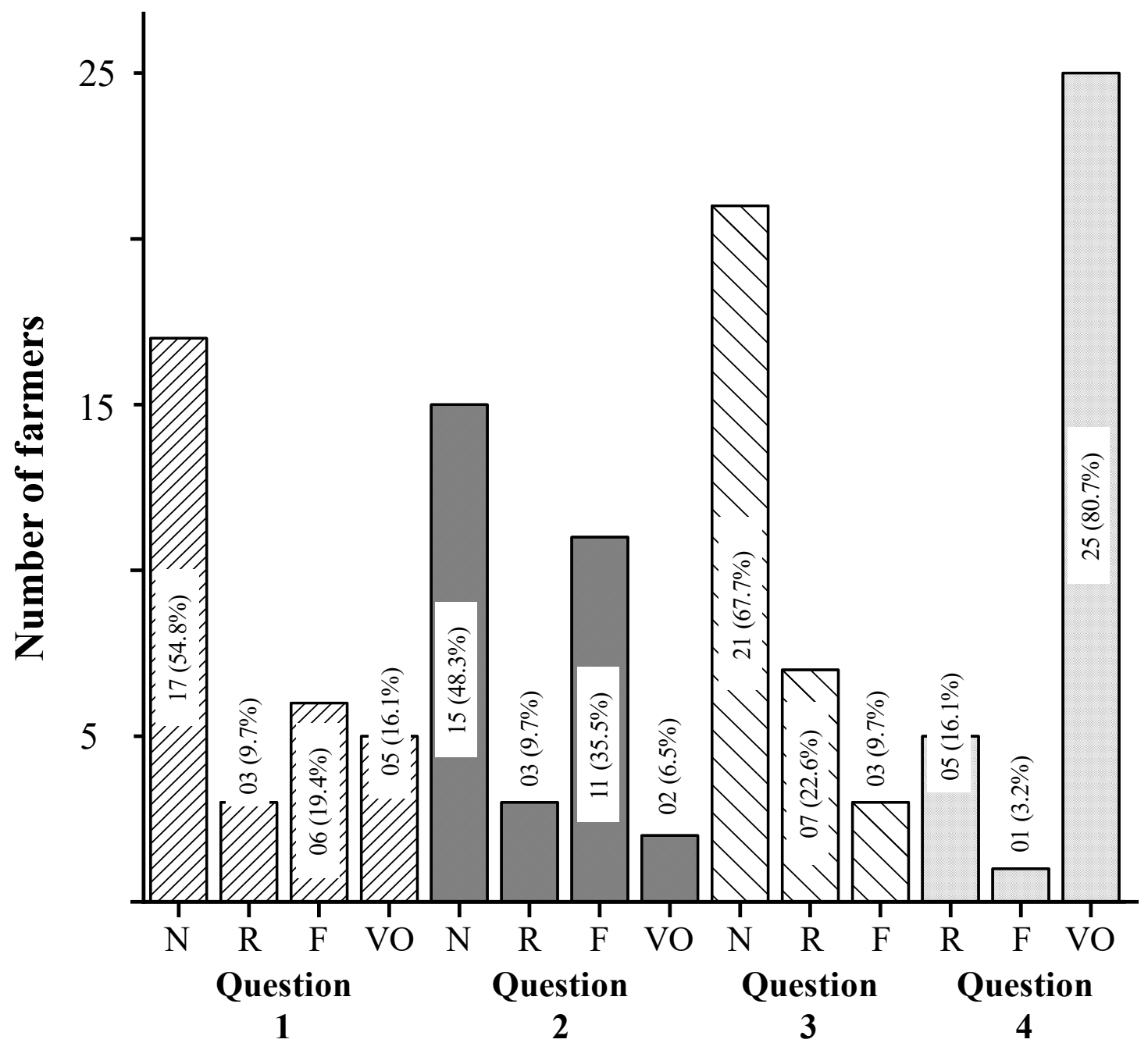

Failure to wash packaging is a common practice in rural properties across the country. The results presented are similar to the study by Sousa et al. (2016), who showed percentages of $47 \%$ never referring to farmers who carried out the triple washing. In another survey, Rocha et al. (2016) reported that, of the 21 interviewees, only one claimed to perform the triple wash. Gomes et al. (2018) also observed that $100 \%$ of the interviewed farmers rarely carried out the practice of handling empty packages on the property regarding triple washing.

The issuance of proof of delivery of empty packaging by the resellers, despite foreseen in Law No. 9,974/2000 (Art. 55), is not carried out in $80.6 \%$ of the cases (Figure 6). Producers who receive, even if rarely (19.4\%), do not keep the receipt (Law No. 9,974/2000, Art. 53, $₫ 3$ ), as they are not charged by resellers $(87.1 \%)$, by inspection agencies $(96.8 \%)$ and for not being informed $(77.4 \%)$ 
about the penalties that are subject to the inappropriate destination of empty packaging (Law No. 7,802/1989, Art. 15).

Figure 6. Family farmers' perception of reverse logistics regarding the return receipt of the packaging: Question 1: Does the collection station always deliver a receipt for the packaging? Question 2: Do you keep the purchase invoices and return receipts for empty packages on file for inspection purposes? Question

3: When you make a new purchase of crop protection products, is the retailer charged for the empty packaging from the last purchase? Question 4: Do you regularly receive supervision over the storage, transport and return of empty pesticide packaging? Question 5: Are you informed of the penalties applied for the inappropriate disposal of empty packaging? N: never; A: rarely; F: frequently; VO: very often. ( $\mathrm{n}=$

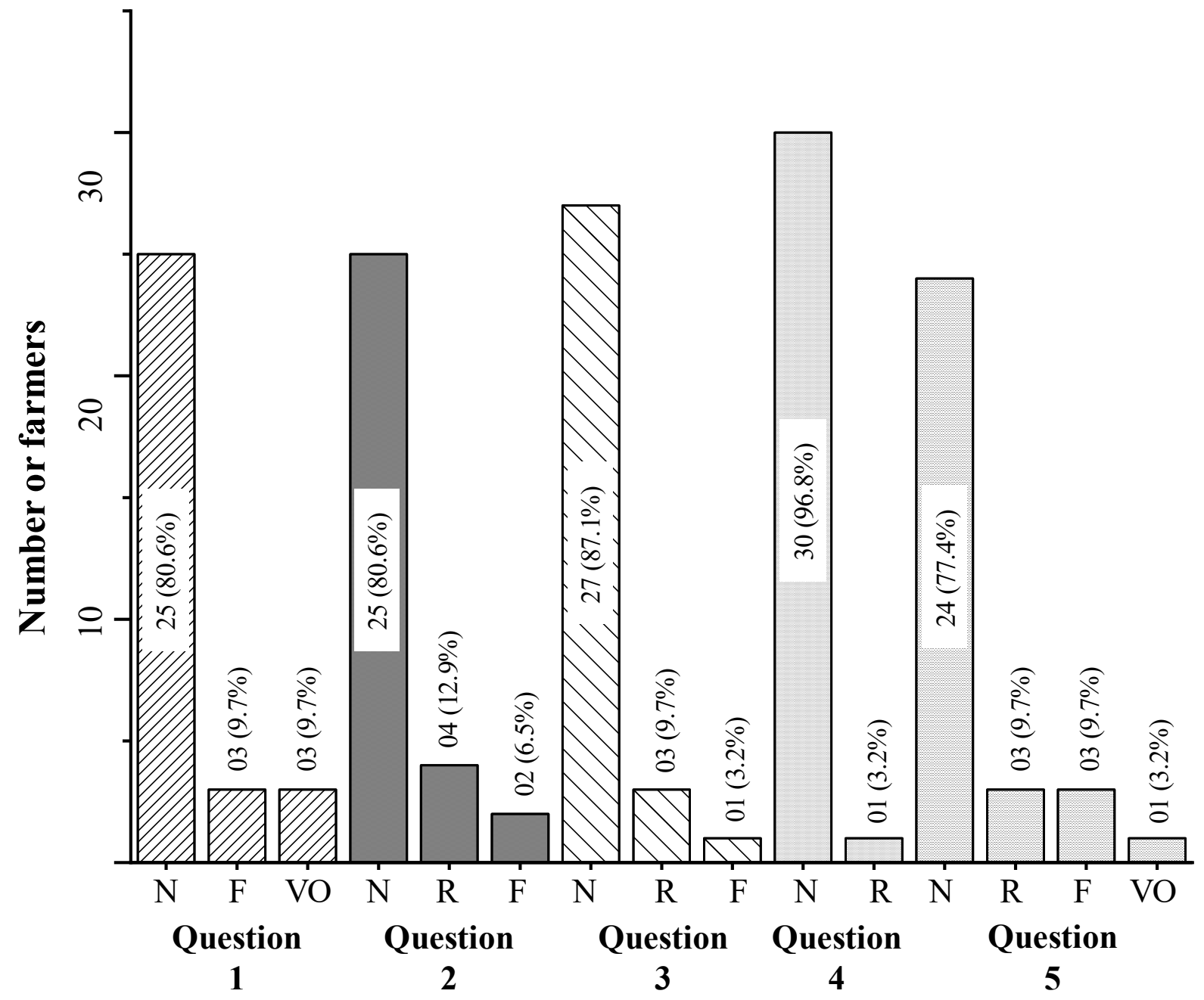

The results point to the absence of mechanisms for the control and inspection of pesticides, by the government (Law No. 7,802/1989, Art. 12A), not only in Arapiraca/AL, but in other regions of Brazil, as in the example of Bernardo et al. (2015), in Tupã/SP, who observed the unanimity of rural producers $(n=20)$ who stated that they had never received inspection on the storage, transport or return of packaging, and only one stated that it is charged by the reseller on the return of packaging previous purchases.

Maintained by companies linked to the distribution and sale of pesticides in Alagoas, ADRAAL is the center for receiving empty packaging, responsible for controlling, packaging, reducing volume and 
storage until it is sent to final destination (recycling or incineration). In practice, the invoice requirement for products purchased by the associate (aiming to compare the number of returned packages), the issuing proof of receipt, as well as the inspection and classification of empty packages between washed and unwashed ones, separating them and quantifying them by type and material (Law No. 4,074/2002, Art. 55), considering that they frequently receive the presence of inspection bodies.

They were pointed out as recurring problems, which makes it difficult to return packaging, the lack of inspection by retailers and rural producers by public agencies, mainly due to the low number of inspectors, as well as the lack of knowledge of farmers about their responsibility and duties when buying and using them. Pesticides. For this reason, ADRAAL, together with the public authorities (ADEAL, Municipal Agriculture Departments), developed educational campaigns (Law No. 7,802/1989, Art. 19), based on the itinerant collection of empty pesticide packages, in which they are visits were made to different municipalities in the state, aiming to facilitate the return, mainly of family farmers.

ADRAAL received 2,341 units of rigid plastic packaging for pesticides, with a predominance of producers linked to the agricultural sector (Table 1). Regarding flexible plastic and rigid cellulosic packaging, there was a predominance of collection from resellers, with the return, in 2018, of 1,482 $\mathrm{kg}$ of empty packaging.

Table 1. Census of packaging collected by ADRAAL in Arapiraca/AL, in 2018.

\begin{tabular}{rcccc}
\hline Kind of packing & \multicolumn{5}{c}{ Origin of packaging } & \multirow{2}{*}{ Total } \\
\hline Rigid plastic (units) & Resellers & Farmers & Itinerant & \\
\hline $1.0 \mathrm{~L}$ & 104 & 100 & -- & \\
$5.0 \mathrm{~L}$ & 4 & 45 & -- & \multirow{2}{*}{2,341 units } \\
$10.0 \mathrm{~L}$ & -- & 20 & -- & \\
$20.0 \mathrm{~L}$ & 19 & 159 & -- & \\
Without classification & -- & 337 & $1,553^{*}$ & \\
\hline Flexible plastic $(\mathrm{kg})$ & 462 & 70 & -- & $1,482 \mathrm{~kg}$ \\
Rigid cellulosic $(\mathrm{kg})$ & 940 & 10 & -- & \\
\hline
\end{tabular}

${ }^{*}$ Quantity referring to the collection of 73 rural farmers.

The data show that there are no integrated control mechanisms that are capable of measuring the number of packages sold and collected, with no confrontation between purchases and returns. It was also found that the collection, through itinerant receipt, exceeded the returns resulting from shared responsibilities (producers/resellers), indicating that this consists of an efficient mechanism that predominated in Arapiraca/AL.

ADEAL is the state inspection agency that acts in all stages of the pesticide use chain, involving the agricultural, health and environment sectors (Law No. 4,074/2002, Art. 71, "a" - "g"). Even with these attributions, it has a limited staff of 10 employees, responsible for inspecting the 30.5 thousand agricultural establishments in Alagoas that use pesticides (IBGE 2019a), in addition to resellers and companies linked to the agrochemical sector. According to Marques et al. (2016), the 
lack of inspection, confirmed in this research (Figure 6), promotes the tendency among farmers to not comply with the legislation, and may therefore have contributed to the $74.1 \%$ of farmers who did not return the empty packaging, providing inadequate final destination (Figure 4). In addition to this limitation, there is the absence of a computerized system, responsible for increasing the efficiency of inspection, from the control of product sales and return of packaging.

Even with the lack of support from the Federal Government, provided for in Law No. 7,802/1989, ADEAL's actions together with the private sector, such as the agreement with ADRAAL, regarding itinerant receipt of packaging, have been successful in significantly reducing (Table 1), the volume of packaging in the field.

In 2017, 15 inspections were carried out in Arapiraca commercial establishments for inspection/ inspection, with irregularities observed in 11 companies (91.7\%), in which the most frequently observed records were the lack of environmental licensing, sale of pesticides without prescription agronomic (or sale of the product and subsequent issuance of the prescription), featuring illegal exercise, and the absence of a Federal Technical Registry of Potentially Polluting Activities (CTF/ APP), in addition to the absence of deposit or inadequate packaging storage facilities, absence of a work safety (Environmental Risk Prevention Program, Occupational Health Medical Control Program and occupational health medical examinations of workers), and absence of registration of the establishment at ADEAL (Figure 7).

Figure 7. Irregularities observed in inspections by ADEAL, in 2017.

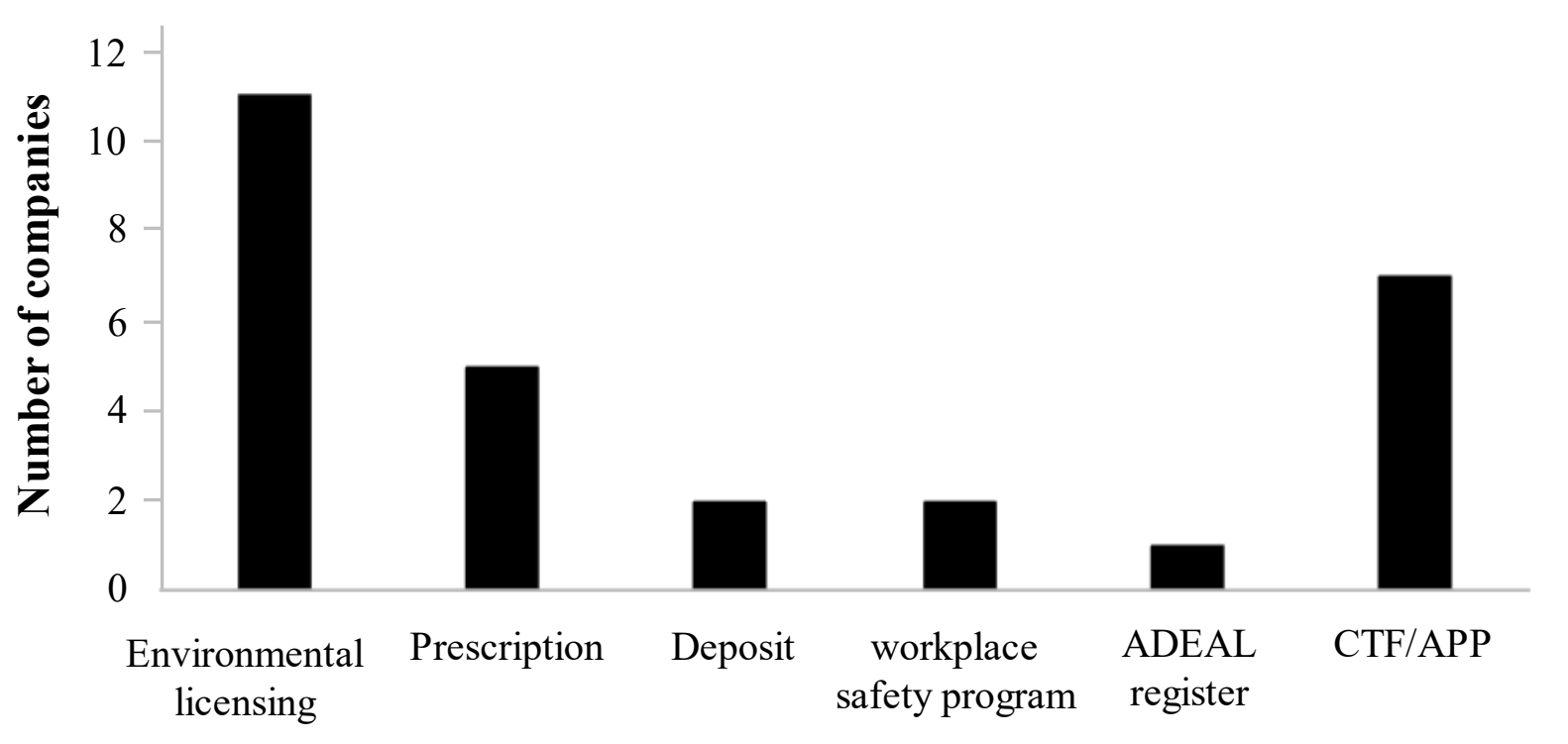

\section{Observed infractions}

It can be inferred from the results presented that the use of pesticides in disobedience to the legislation as to safe and correct use harm both the environment and human health, losses that are intensified by the difficulties faced by family farmers in Arapiraca/AL, reflecting on compliance responsibilities within the reverse logistics process for empty pesticide packaging. Thus, the negligence in relation to adequate procedures and the neglect of human actions regarding the use of pesticides verified in the research, are indicators for the creation of preventive measures to be adopted. 


\section{Conclusions}

The pesticide reseller companies claim to follow the legislation, although, in inspections, there was an absence of environmental licensing and the products were sold without the agronomic prescription. The producers stated that they do not return the pesticides packages and that they often bury or burn them, that they do not receive technical guidance at resellers, nor inspection on their properties, reflecting the inadequate handling of products, packaging, and exogenous intoxications.

ADRAAL reported limitations regarding the uninformed producer; to resellers, which make it possible to present legal information to the producer at the time of sale; to the public authorities, with deficient inspection; in addition to the absence of educational programs, the reverse logistics process is inefficient. ADEAAL informed that it has a limited staff, does not have a computerized monitoring/control system and performs integrated actions with other public agencies.

Participação dos autores: SMB - mestrando do Programa de Pós-Graduação em Tecnologias Ambientais (PPGTEC), responsável pela condução da pesquisa, obtenção dos resultados, tabulação e interpretação; MC - docente do PPGTEC, orientador, responsável pelo projeto de pesquisa, auxílio na interpretação, discussão dos resultados e redação científica do artigo.

Aprovação ética ou licenças de pesquisa: $\mathrm{O}$ projeto foi submetido à análise do Comitê de Ética em Pesquisa CEP/ Cesmac, tendo sido aprovado "sem óbices éticos" sob o número 3.448.573, de acordo com a resolução CNS n 510/16.

Disponibilidade dos dados: Pesquisa resultado da dissertação de mestrado do primeiro autor. Repositório do Ifal: https://www2.ifal.edu.br/ppgtec/tccs/arquivos/tcc-socrates-mesquita-bomfim.pdf

Fomento: Não houve auxílio financeiro de órgãos de fomento para condução da pesquisa.

Conflito de Interesses: Os autores declaram não haver conflito de interesses.

\section{References}

Bernardo CHC, Braga Júnior SS, Marques MD, Gomes SCV, Queiroz TR. 2015. Percepção dos produtores rurais de Tupã, SP, sobre o processo de comunicação para execução da logística reversa de embalagens de agrotóxicos. Revista Observatório, 1(3):242-270. DOI: 10.20873/uft.2447-4266.2015v1n3p242.

Bomfim SM, Cavalcante M. 2019. Exageneous intoxications in Alagoas, Brazil: pesticides emphasis. Revista Gaia Scientia, 13(4):1-10. DOI: 10.22478/ufpb.1981-1268.2019v13n4.44460.

Cavalcante M, Bomfim, SM. 2020. Socioeconomic characterization of family farmers, trade, use and poisoning by pesticides in Arapiraca/AL, Brazil. Revista Gaia Scientia, 14(1):179-192. DOI: 10.22478/ufpb.1981-1268.2020v14n1.50522.

Gomes VEV, Araújo RCP, Francelino VI. 2018. Manejo dos agrotóxicos e das suas embalagens vazias em propriedades rurais no Estado da Bahia. Atas de Saúde Ambiental, 6(1):46-70.

IBAMA (Brazilian Institute of the Environment and Renewable Natural Resources). 2019. Relatórios de comercialização de agrotóxicos. Available at: <https://www.ibama.gov.br/agrotoxicos/relatorios-de-comercializacaode-agrotoxicos\#sobreosrelatorios>. Accessed on: 15 Dec. 2019.

IBGE (Brazilian Institute for Geography and Statistic). 2019b. Arapiraca: Panorama. Available at: <https://cidades.ibge. gov.br/brasil/al/arapiraca/panorama>. Accessed on: 15 Jan. 2019.

IBGE (Brazilian Institute for Geography and Statistic). 2019a. Censo Agro. Available at: <https://censoagro2017.ibge. gov.br>. Accessed on: 12 Apr. 2019. 
Leite SA, Castellani MA, Ribeiro AEL, Moreira AA, Aguiar WMM. 2016. Perfil dos fruticultores e diagnóstico do uso de agrotóxicos no polo de fruticultura de Livramento de Nossa Senhora, Bahia. Extensão Rural, 23(2):112-125. DOI: $10.5902 / 2318179613538$.

Leiva JA, Nkedi-Kizza P, Morgan KT, Qureshi JA. 2015. Imidacloprid sorption kinetics, equilibria, and degradation in sandy soils of Florida. Journal of Agricultural and Food Chemistry, 63(20):4915-4921. DOI: 10.1021/acs.jafc.5b00532.

Marques MD, Braga Júnior SS, Merlo EM, Martinez MP. 2016. Percepção dos revendedores e centrais de coleta do inPEV na região da Alta Paulista, como participantes da logística reversa das embalagens de agrotóxicos. Sustentabilidade em Debate, 7(3):62-78, 2016. DOI: 10.18472/SustDeb.v7n3.2016.18350.

Miot HA. 2011. Tamanho da amostra em estudos clínicos e experimentais. Jornal Vascular Brasileiro, 10(4):275-278. DOI: $10.1590 /$ S1677-54492011000400001.

Nogueira VBM, Dantas RT. 2013. Gestão ambiental de embalagens vazias de agrotóxicos. Revista Tema, 14(20):22-34.

Munõz-Leoz B, Ruiz-Romera E, Antigüedad I, Garbisu C. 2011. Tebuconazole application decreases soil microbial biomass and activity. Soil Biology and Biochemistry, 43(10):2176-2183.

Murakami Y, Pinto NF, Albuquerque GSC, Perna PO, Lacerda A. 2017. Intoxicação crônica por agrotóxicos em fumicultores. Saúde em Debate, 41(113):563-576. DOI: 10.1590/0103-1104201711317.

Pignati WA, Lima FANS, Lara SS, Correra MLM, Barbosa JR, Leão LHC, Pignatti MG. 2017. Distribuição espacial do uso de agrotóxicos no Brasil: uma ferramenta para a Vigilância em Saúde. Ciência \& Saúde Coletiva, 22(10):3281-3293. DOI: $10.1590 / 1413-812320172210.17742017$.

Raymann K, Motta EVS, Girard C, Riddington IM, Dinser JA, Moran NA. 2018. Imidacloprid decreases honey bee survival rates but does not affect the gut microbiome. Applied and Environmental Microbiology, 84(13):1-13. DOI: 10.1128/AEM.00545-18.

Rocha TALCG, Oliveira FN. 2016. Segurança e Saúde do Trabalho: vulnerabilidade e percepção de riscos relacionados ao uso de agroquímicos em um pólo de fruticultura irrigada do Rio Grande do Norte. Gestão \& Produção, 23(3):600-611. DOI: 10.1590/0104-530x1219-14.

Santana CM, Costa AR, Nunes RMPM, Nunes NMF, Peron AP, Cavalcante AACM, Ferreira PMP. 2016. Exposição ocupacional de trabalhadores rurais a agrotóxicos. Cadernos de Saúde Coletiva, 24(3):301-307. DOI: 10.1590/1414$462 \times 201600030199$.

Serra LS, Mendes MRF, Soares MVA, Monteiro IP. 2016. Revolução Verde: reflexões acerca da questão dos agrotóxicos. Revista CEDS, 1(4):2-25.

Silva RN, Silva JM, Silva WC. 2013. Horticultores e agrotóxicos: estudo de caso do Município de Arapiraca (AL). Revista Ibero-Americana de Ciências Ambientais, 4(1):6-68. DOI: 10.6008/ESS2179-6858.2013.001.0005.

Song Y, Kai J, Song X, Zhang W, Li L. 2015. Long-term toxic effects of deltamethrin and fenvalerante in soil. Journal of Hazardous Materials, 289(1):158-164. DOI: 10.1016/j.jhazmat.2015.02.057.

Sousa JA, Feitosa HO, Carvalho CM, Pereira CF, Feitosa SO, Silva SL. 2016. Percepção dos produtores rurais quanto ao uso de agrotóxicos. Revista Brasileira de Agricultura Irrigada, 10(5):976-989. DOI: 10.7127/rbai.v10n500484.

Veiga MM. 2008. Flaws in Brazilian take-back program for pesticide containers in a small rural community. Management Research News, 32(1):62-77. DOI: 10.1108/01409170910922032. 